SAD / JSR

Sosyoloji Araştırmaları Dergisi / Journal of Sociological Research

Cilt / Volume 23 Say1 / Number 2 (Ekim / October 2020) : (244-283)
Araştırma Makelesi / Research Article

Geliş Tarihi / Submited: 13.11.2019

Kabul Tarihi / Accepted: 10.06.2020

\title{
DISCURSIVE GOVERNANCE OVER PRO-POPULATION POLITICS IN TURKEY
}

\author{
Ezgi PEHLIVANLİ-KADAYİFCí ${ }^{1}$ \\ Hande ESLEN-ZIYYA ${ }^{2}$ \\ Umut KORKUT ${ }^{3}$
}

\begin{abstract}
Discursive governance of pro-population politics refers to norm-based mechanisms of governance that utilise intentionally selected slogans in political discourse for dissemination of ideas to further the interests of political authorities. Such ideas can be disseminated via modern communication technologies enabling governance to build social representations within the public sphere without policy constraints. It is our proposal that the pro-population state discourse in Turkey after 2008 constitutes an example of discursive governance. Our findings show that discursive mechanisms can lead to a change in married couples' reproductive attitude without significant policy alteration and further the debate in view of discursive governance of population politics.
\end{abstract}

Key Words:Discursive Governance, Pro-Population Politics, Women, Behaviour Change, Turkey

${ }^{1}$ Araş. Gör. Dr., Orta Doğu Teknik Üniversitesi, Bilim ve Teknoloji Politikaları Araştırma Merkezi

2 Doç. Dr., Stavanger Üniversitesi, Medya ve Kültürel Çalışmalar Bölümü

${ }^{3}$ Prof. Dr., Glasgow Caldedonian Üniversitesi, İşletme ve Toplum Bölümü

SAD / JSR

Cilt / Volume 23 Sayı / Number 2 


\section{SÖYLEMSEL YÖNETISŞIM ÖRNEĞİ OLARAK TÜRKİYE'DE NÜFUS YANLISI POLITIKALAR}

\section{ÖZ}

Nüfus yanlısı politikaların söylemsel yönetişimi; siyasal otoritelerin çıkarlarını sürdürmek adına politik söylemde fikirlerin yayılması için kasıtlı olarak seçilen sloganları kullanan norm tabanlı yönetişim mekanizmalarını ifade eder. Bu tür fikirler, siyasa üretme kısıtı olmaksızın yönetişimin kamusal alan içinde sosyal temsiller oluşturmasını sağlamak yoluyla modern iletişim teknolojileri aracılığıyla yayılabilir. Bu çalışmada, 2008'den sonra Türkiye'deki nüfus yanlısı devlet söyleminin söylemsel yönetişime örnek teşkil ettiğini savuınuyoruz. Elde ettiğimiz bulgular; söylemsel mekanizmaların, direkt siyasa yapılanması olmadan evli çiftlerin üreme tutumlarında bir değişikliğe yol açabileceğini göstermektedir. Bu çalışma bulguları çerçevesinde, söylemsel nüfus politikası örneği üzerinden yönetişim tartışmalarına yeni bir boyut kazandırmayı amaçlamaktadır.

Anahtar Kelimeler: Söylemsel Yönetişim, Nüfus Yanlısı Politikalar, Kadın, Davranış Değişimi, Türkiye 


\section{INTRODUCTION}

The early 2000s witnessed the circulation of political declarations concerning pro-population policies in Turkey (Ünal \& Cindioğlu, 2013, Altunok, 2016; Korkut, \& Eslen-Ziya, 2017). This, in turn, created a discursive space about reproduction choices. "At least three children", "incentive per child" and "abortion is murder" have been and still are the commonly used slogans of such declarations. If we consider discourse and metaphors as integral components of narrative and constitutive of sociocultural relations, we should address their power to highlight features of reality and even hide others (Koller, Veronika, 2005; Van Dijk, 1998). We can thereby explore to what extent political discourses can become normative mechanisms by socially constructing realities in the political space and using intentionally selected slogans to influence the public sphere.

In this paper, it is proposed that the modernist modes of social control and standardised bureaucratic genres (Lemke, 2000) came at the closure of traditional institutional social formations of discipline (Lemke in Weiss \& Wodak, 2003). Foucault (1984) introduced the term 'bio-power' to designate forms of power exercised over people as living beings: a politics concerned with subjects as members of a population, in which issues of individual sexual and reproductive conduct interconnect with issues of national policy and power. It is different from previous forms of discipline that were based on the ability to kill / end / destroy. What distinguishes biopower from previous techniques of power is its new preoccupation with the management, regulation and administration of populations through the imposition of self-discipline. Biopolitics is the moment when politics assumes it provides the right to live within a controlled, limited space, as an object of direct intervention (Esposito, 2010, p. 17). It is a power that becomes embedded and regularised throughout society and its populations. It is a political rationality that takes the administration of life and populations as its subjects and is comprised of strategies and mechanisms through which human life processes are managed under regimes of authority over power and the processes of subjectivation.

$\mathrm{SAD} / \mathrm{JSR}$

Cilt / Volume 23 Sayı / Number 2 
The literature concerning new types of governance is not new (Foucault, 1990; Agamben, 1998; Lemke, 2000; Esposito, 2010; Collier, 2009). The dominant discursive technology of late modernism has been the standardised text or discourse, which functions to organise society on larger scales (Agamben, 1998: 119). Mentioned literature reformulates the ancient power of the sovereign - 'to kill or to let live' - into the modern bio-power - 'to make live and to let die' (Agamben, 1999: 82-83). In that sense, this paradigm proposes that the main operation of governing deals particularly with the biopolitical 'administration of life' (Žižek, 2004: 509). Hence, bio-politics of population is regulatory rather than disciplinary regarding the right to live. Such political rationality does not work through controls of the body or a direct policy change to ensure the behaviour shift. Instead, it aims to 'establish a sort of homeostasis, and compensate for variations within general population' to "optimize a state of life" (Foucault, 2003: 246). This integration between regulatory and disciplinary power exemplifies the mechanisms of discursive governance as a form of bio-power that operates with the right to live through pro-population discourses in Turkey.

Discursive governance, used by Korkut et al. (2016) to refer to implicit mechanisms of governance that depend on narratives and strategic metaphors in political language to socially construct an amenable environment for the dissemination of ideas, furthers the interests of political authorities. Such ideas can be broadly and rapidly disseminated via modern communication technologies, enabling governance to build implicit social representations within the public sphere without policy constraint. In this sense, mechanisms of discursive governance are an analysis of how technologies of power are configured in assemblies of government. They not only ensure the distribution of ideas for a directed social change, they also prevent possible political conflict at the state level by not requiring comprehensive policy development.

Our study on discursive governance aims to demonstrate that pointing transformations in discourse and realising them in practice depends only on the 'performance of a sovereign power' (Blüdhorn \& Butzlaff, 2019). It is the Justice and Development Party (AKP)'s sovereignty claims that have created the pro- 
population discourse since 2008. In this respect, this paper examines the influence of political discourse in governance processes by analysing the circulation of the pro-population discourse in Turkey. We argue that this is a unique type of governance through which normative mechanisms constructed by political discourses are deployed in the public sphere without accompanying policy changes. Noted before by Korkut and Eslen-Ziya (2016:34), the ideas operate as tools that adjust the public to the new politic. In the new era of politics, there is a uniqueness of apparatus produced through mixes of standardised elements (apparatus, procedures, discourses, slogans) from the political sphere. Simultaneously, political discourses permit much faster rates of change in texts. In our case, the main text is on pro-population discourses that we argue that might lead to a relatively rapid change in individual development; without the need for institutional changes, actors use strategic discourses. This paper, by taking a step further from the discursive governance analysis of Korkut and Eslen-Ziya (2016), aims to provide an understanding of how pro-population discourses in Turkey influence the public. In other words, we are interested in understanding how individuals make choices regarding abortion, c-sections and/or reproduction and whether they are influenced by the dominant discourses presented by the government. Thereby, this study aims to elaborate on change in public opinion following the positions of discourse subjects.

A growing body of literature exists on how reproduction and gender has turned into a most visible grounds for political struggle in late modern societies (Acar \& Altunok, 2013; Korkut \& Eslen-Ziya, 2016; K1lıç \& Göçmen, 2018; Dayı \& Karakaya, 2018). Nonetheless, an analysis of how issues regarding reproduction have become subject to regulatory mechanisms within purposes related to population at a national level is lacking. 
We propose that the authoritarian AKP has reinforced patriarchal and traditional gender identities and roles in Turkey since 2008. President Erdoğan, Prime Minister at the time, first stated ${ }^{4}$ in March 2008 that to overcome the adverse effects of economic stagnation, each family in Turkey should have at least three children:

"One or two children mean bankruptcy. Three children mean we are not improving but not receding either. So, I repeat, at least three children are necessary in each family, because our population risks aging. We are still on the good side, as we still own a young and dynamic population. But we are slowly aging. Presently, the whole western world is trying to cope with this problem. Please do not take our susceptibility lightly, this is a very serious issue."

Our argument is based on the supposition that pro-population discourses in general, and in particular Erdoğan's above, mention the three-children discourse to specifically impact the reproductive attitudes of people. We focus first on the possibility of deciding to have three children and second on the reluctance towards abortion due to the influence of a pro-population political discourse. As conservative propopulation discourse has a particular emphasis on the family as the moral and legitimate site of reproduction, we argue that within this context women's rejection of the ban on abortion or having three children is significant. Such a claim explores the functioning of state discourse which operates through the presence of a sovereign figure (Övünç \& Zengin, 2019) with new political instruments, including slogans, polarising discourse and re-contextualised elements of traditional genres and forms (Lemke, 2001) that hold on to women's bodies in the name of the population. By focusing on women's narratives, we aim to discuss people's understandings of themselves as reproductive actors and parts of biopolitical relations - the couple, family and society (Polat, 2020; Zizek, 2004; Esposito, 2010).

\footnotetext{
${ }^{4}$ https://www.hurriyetdailynews.com/turkish-pm-erdogan-reiterates-his-call-for-three-children-38235, Accessed on 26.09.2020. $\mathrm{SAD} / \mathrm{JSR}$

Cilt / Volume 23 Say1 / Number 2 
The Turkish political discourse emphasizes women's caregiver roles within the family, often identifying womanhood exclusively with motherhood, an approach resulting in the implicit neglect of gender equality concerns (Acar \& Altunok, 2013; Day1 \& Karakaya, 2018). On the basis of this particular perception, we argue that population issues need to be handled from a gender perspective in addition to the discursive governance paradigm, which would provide a productive and critical discussion that is needed in population as well as political studies. In order to elaborate our argument, we will first focus on the pro-population declarations of statesmen in Turkey. We will then foster our argument with respect to the findings of our research.

The main argument of this study is hence to explore whether ideas dispersed in the public sphere may affect discourse subjects and instigate new attitudes - or even behavioural change. To reach our aim we will examine the implications of the three child discourses for the public through the analysis of in-depth interviews, where we study the reflections of such discourses within the public. Since discourses can create representations "that not only reflect upon but also actively construct reality by ascribing meanings" (Van Dijk, 1998: 8) to our world, identities and social relations, we believe that the in-depth interviews conducted in this research will help us understand how such normative mechanisms have influence individual decisions. To accomplish this, we took the AKP's pro-population discourse, reflected by the emphasis on having at least three children, as a case study for understanding the dynamics of discursive governance and focused on the registration of such politics in attitudes and behaviour. Our subjects included women and men (nine women and one man) who hold a low socioeconomic status. Because we wanted to study the influence of three child discourses on people's decisions, we included participants who had three children or were expecting their third. We created three sets of questions: one for males, one for females and one for participants from the health profession. To grasp the possible transformation in the health system towards the pro-population discourse, we also conducted an interview with the General Coordinator of Turkish Family Health and Planning Foundation. To collect information from two public health clinics, we 
interviewed a nurse and medical practitioner about their services and elicited their opinions on the real effects of the pro-population discourse.

Following two pilot studies, the semi-structured questionnaire was finalised. The interviews ${ }^{5}$ were carried out in İzmir and Ankara, usually in participants' homes with children present. Interviews started with demographic questions, followed by questions about their experiences. The participants did not allow recording; the interviewer took notes during the sessions. The transcriptions and fieldwork notes constituted the main data set of this study. For the privacy of participant identities, we will refer to them anonymously, from P1 to P10. Both data sets were analysed via the thematic analysis research method. Nvivo12 was used to systematically code and analyse the raw data and develop and incorporate the developing analytic categories and themes. The first stage of open coding or line-by-line coding was used to produce expressive and summative codes for the experiences and perceptions of participants as close as possible to participants' original words. This was followed by focused coding, whereby the most recurrent initial codes were organised under "code families". The project team pursued reaching agreement during the process of coding and conducted the coding according to the relevant literature. Once the common code book was shaped, all the interviews were coded and later brought together under code families. Based on the analysis of code families, the research team came up with the most salient categories in the different domains of interest. These categories formed the basis for the organisation of the results section. For the overall profile of participants, please see Table 1 below.

\footnotetext{
${ }^{5}$ It is important to note that the research process could have been affected by the adverse atmosphere following the coup attempt in Turkey on 15 July 2016. Though interviews were planned to be conducted during the summer of 2016, they were either cancelled or postponed to unknown dates. Also, male participants preferred not to participate. Hence, we only had access to women's narratives and a small sample size.
}

$\mathrm{SAD} / \mathrm{JSR}$

Cilt / Volume 23 Say1 / Number 2 


\section{Table 1. Profile of the Participants}

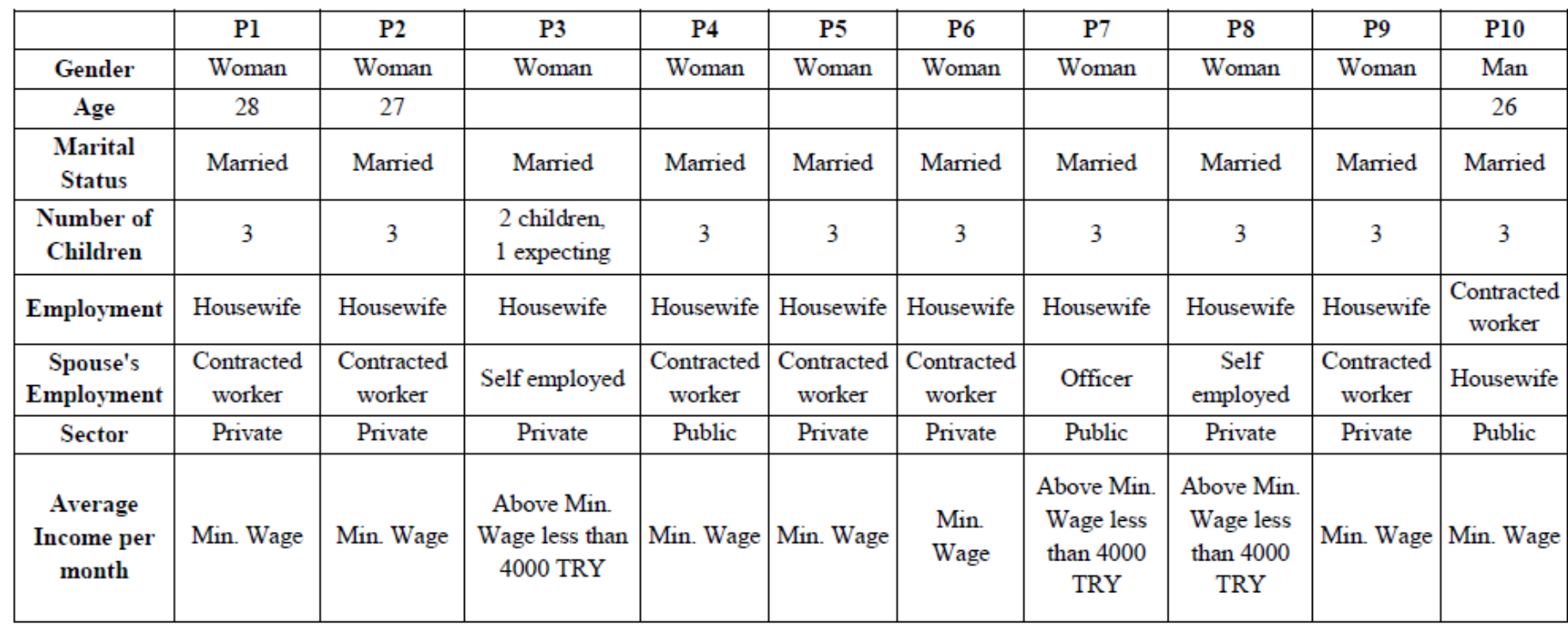




\section{CONTEXTUAL BACKGROUND: PRO-POPULATION DISCOURSE IN} TURKEY

The peculiarity of the Turkish case originates from conflicting figures concerning its population growth. According to the Turkish Statistical Institute, the fertility rate in 2019 was 1.88 births per mother. However, even if population decline is not an alarming issue, pro-population has, especially since 2008, become a major topic of the AKP government (Van Dyck, 2013). Pro-population politics embedded in conservative discourse about family and reproduction has been an official subject of the state in Turkey.

Conservative state discourse here refers to the encouragement of family as the kernel of the social order. Strengthening the traditional family institution is viewed as an effective remedy to social problems and other attendant risks of modernisation and economic crises (Buğra, 2007). Family has been a significant element of the pro-population discourse since 2008 in many contexts (Korkut \& Eslen-Ziya, 2016). It has been an important site where authority and patriarchy are reaffirmed within the institution of family as the intimate relationship of binary genders. The institution itself reinforces the disciplinary and regulatory mechanisms of the state. Conversely, within the framework of conservative ideology, institutions, citizens or political relations are conceived in the image of a family. Prevalent discourse in Turkey can be seen through various formations for the sake of pro-population ideology. It contains encouragement for more children, policies such as longer parental leave, anti-abortion implications, family benefits and strict monitoring of pregnancy via provincial clinics.

In this ideology, traditional family is based on a hierarchy where men are superior to women (Arat, 2010). Patriarchal hierarchy emphasises the separation of lives, as woman's work is in the private sphere and man's work is in the public sphere (Sunar, \& Fişek, 2005; Boratav et al., 2014). As Kandiyoti also states, the patriarchal family structure in Turkey is still valid: men have the authority over everyone else and are "bound up in the incorporation and control of the family by the state" (Kantiyoti, 1998). The conservative conventions expect Turkish women to serve as the guardians of tradition and custom in their roles as good 
mothers and wives. Having made women into the mothers of the country, a religious nationalism then turns around and burdens them with the responsibility to carry on the traditions that are supposedly emblems of national identity conceived in terms of a religion dictated from above (Dirlik, 2012). The conception of women as 'sacred' mothers, keystones of the family structure and guardians of the moral-cultural order has been strongly emphasised by governments in Turkey (Müftüler-Bac, 1999).

The pro-birth rhetoric of the AKP government also reflects an anti-abortionist emphasis. Their anti-abortion discourse, articulated in a variety of political declarations, politicised women's reproductive choices. On 26 May 2012, during the closing session of the Parliamentarians' Conference of the UN Population Fund (UNFPA), Erdoğan vehemently opposed the practices of abortion and caesarean births in Turkey. In his speech, he made an analogy between abortion and an air strike by the Turkish military that killed 34 civilians in Uludere in December 2011 by declaring that 'every abortion is Uludere' ${ }^{6}$ :

'I am a Prime Minister who opposes Caesarean births, and I know all this is being done on purpose. I know these are steps taken to prevent this country's population from growing further. I see abortion as murder, and I call upon those circles and members of the media who oppose my comments... I say every abortion is Uludere ... we are preparing the abortion legislation and we will pass it'.

The Uludere incident took place during Erdoğan's rule. Many civil society organisations and families of the killed citizens called for an official investigation and punishment of those responsible for the operation. A report prepared by the Parliamentary Commission, established in March 2012 to investigate the affair, declared that the incident was a 'tragic accident' and happened due to communication flaws between

${ }^{6}$ http://www.hurriyetdailynews.com/abortion-sparks-raging-debate-in turkey.aspx?pageID=238 \&nID=21740\&NewsCatID=339 Accessed on 13.05.2020

$\mathrm{SAD} / \mathrm{JSR}$

Cilt / Volume 23 Sayı / Number 2 
civilian and military authorities. The Military Prosecutor's Office, on the other hand, dismissed the investigation. While the analogy made by Erdoğan might seem at first to be irrelevant, the logic of the analogy relates the tragic accident to the deliberate ending of an embryo's life. Moreover, it is also the manifestation of a certain political rationale that aims to subjugate women by advocating a moral order via political declarations about reproduction and family (Altunok, 2016).

We argue that a conservative, pro-population ideology is a political rationality whose purpose is to regulate individual conduct among the general population that is consistent with its interests by creating discursive normativity. One obvious instance for discursive influence is the Prime Minister's encouragement of "three children," which even became a slogan that was excessively circulated by the media to awaken the idea that Turkey needs a large population in order to maintain its economic stability and national identity (Altunok, 2016:140). These sentiments continue to be espoused by Erdoğan's presidency and repeated by his successor, Prime Minister Ahmet Davutoğlu (Prime Minister between August 2014-March 2016). The idea of three children is legitimised by drawing attention to aging populations in European countries and, through state declarations, warning of a possible decrease in Turkey's population growth.

In several circumstances, Erdoğan's statements concerning abortion and c-sections were supported by AKP statesmen and The General Directorate of Religious Affairs (Diyanet). According to Y1lmaz, in Turkey social conservatism focuses on the "regulation of sexuality and gender relations" (Y1lmaz, 2008: 59). It is based on an idealised version of the hardworking woman in the holy family. Within this frame, religion can become a supportive ideology that legitimises family as a holy constituent of the social structure (Y1lmaz, 2008). A recent example of this alliance between politics and religious authorities can be found in Erdoğan's speech from 30 May 2016, warning Muslim families against birth control, this time as the President of the state. Erdoğan declares that Muslims need to reject contraception, which he declares to be "treason", and 
instead have more children to "multiply our descendants". He also claims that a woman who rejects motherhood is "deficient" and "incomplete"7:

In addition to politicians' declarations, public service broadcasting also encourages natural birth and breastfeeding. Provincial clinics perform strict monitoring through pre- and postnatal processes. Moreover, in order to support employed couples, the state has promised amendments concerning longer maternity leave, laws for the protection of female employees and increasing monetary incentives for every additional child. However, apart from the monetary incentives for additional children, these incentives have been kept on the discursive level. In 2010, a pro-natalist policy was enacted, supported by an amendment to the "Regulation Concerning Treatment Centers for Assisted Procreation", which permitted the use of assisted reproductive technologies, though only for heterosexual and married couples, with the process to be terminated at the death (of the husband) or in the case of divorce (Day1 \& Karakaya, 2018). Although there has been no official change in the abortion law, this unofficial pronatalist discourse has been successful at limiting access to abortion and birth control by putting pressure on medical providers (Day1 \& Karakaya, 2018). O’Neil from Kadir Has University, (2017) has documented the decrease in abortions in public hospitals throughout Turkey in a survey of state hospitals and teaching state hospitals. Also, others noted a decrease in contraceptive methods, and the beginning of a potential rise in birth rates (TNSA, 2013).

On this basis it is our assertion that the Turkish case constitutes an example of how politicians influence public reasoning by circulating discourses, such as slogans or public declarations, while simultaneously postponing agendas for significant policy change. To support our argument, in the coming section we will show how pro-population discourse after 2008 has influenced reproductive attitudes. By effect, we refer to

\footnotetext{
${ }^{7}$ http://www.bbc.com/news/world-europe-36413097 Accessed on 13.05.2020.
}

$\mathrm{SAD} / \mathrm{JSR}$

Cilt / Volume 23 Say1 / Number 2 
our participant's definition of attitude change and their realisation and deliberate choice to have at least three children in response to the discursive political encouragement.

\section{RESULTS}

Our main focus has been on the implicit mechanisms embedded in the pro-population discourse in Turkey since 2008. Discourse re-creates and transforms the actors who come to recognise and identify themselves as the subjects of its signifying practices (Mahedran \& Vedaldi, 2015). By taking these discursive actions as a form of biopolitical regulation over society, we argue that particular political slogans create narratives within which they set forth certain gender roles and expectations for action. To this extent, we follow the deliberations that public slogans initiate and review their meaningful effect - positive or negative - on the intersubjective construction (Bock-Cote, 2016; Lemke 2000) of having three children. In this regard, our data reveals two opposing poles of participants. In the following section, we will present how such discourses shaped people's lives and their reproductive choices.

\section{Generation and Reception of the "Three Children Discourse"}

This part elaborates how the composition and delivery of pro-population discourse can serve as a form of rule setting for the public as the subjects of the discourse. We argue that there is a process for articulation and formation of the discourse in which the consumers receive ideological messages though strategically identified steps (Chiapello \& Fairclough, 2002). In this respect, the state discourse for pro-population was constructed with three main stages. First, the "at least three children" slogan was proposed for all married couples. Not only did this idea encourage couples to have children, it was bolstered by a pessimistic scenario of population stagnation that alluded to an economic need for a growing, young population. This view was further supported by examples of countries with large populations, comparing their economic conditions to 
Turkey's and imposing the idea that economic success can only be achieved by population growth. ${ }^{8}$ Moreover, European states were cited as adverse examples of population governance. Throughout the construction of "at least three children", statesmen also referred to nationalistic ideals for economically promising and religious generations ${ }^{9}$. The second stage concerns the abortion ban and influence on the discussion of abortion as murder. For this we asked our participants whether they agreed with the restrictions on abortion services. Our aim was to understand respondents' perspectives regarding abortion within the current discussions. The third stage in this ideological construction was the attack on caesarean births, where the pro-population discourse was supported by religious texts. ${ }^{10}$ In 2016 , contraception was even declared to be against Islam, and Muslims were advised to forsake birth control. ${ }^{11}$ In this paper's conceptualisation, we call such stages 'discourse generation', which implies strategic calculations embedded within the quality of discursive composition. Given the sequence and appropriation of propopulation declarations, it can be argued that this discourse promotes rule setting and fosters taken-forgranted behaviour by affecting conduct. This was evident in the following statement from our participant:

What they said ("At least three children") did and did not affect me at the same time. It affected me as an idea. They do not come and forcibly impose it but something happened, I do not know exactly (P4).

\footnotetext{
${ }^{8}$ Erdoğan explains his political perspective on population growth as follows: "The immediate reaction comes: 'Can you afford more children? Can you educate them all? Look, brother, what is the population of China and India right now?? They are one of the richest countries in the world. Do you suppose that their avarage income rate is better than ours? No, it is not. Certain parts of their population have a high income, the rest is worse than ours and we argue the more population we have the more powerful we become. Do not worry about anything."7. "Erdoğan: Make three kids before it is too late", 10.10.2009, NTVMSNBC, http://www.ntvmsnbc.com/id/25008774/ Accessed: 18.07.2013

${ }^{9} \mathrm{http} / / /$ www.yenisafak.com/gundem/dindar-nesil-yetistirecegiz-2424175 Accessed: 18.07.2013

${ }^{10} \mathrm{http}: / /$ www.yenisafak.com/gundem/dindar-nesil-yetistirecegiz-2424175 Accessed: 18.07.2013

${ }^{11}$ http://www.hurriyet.com.tr/gundem/erdogan-bu-ulkede-dogum-kontrolu-ile-yillarca-ihanet-yaptilar-27823289. Accessed:18.07.2013
}

$\mathrm{SAD} / \mathrm{JSR}$

Cilt / Volume 23 Say1 / Number 2 
The participants who had sympathy towards such pro-population discourse implied that they might indeed have been influenced by the idea, unconsciously if not consciously. This indicates a mental process, where there exists a "product of shared cognitive architecture that promotes the spread and persistence of certain concepts" (O'Leary et al., 2011:7) What is significant here is that implicit cognitive mechanisms work both unconsciously and automatically. Therefore, we argue that the direction of action changes with regard to personal position, vis-a-vis the hegemonic political view of the discourse. We found that while some participants who openly declared their support for the AKP responded positively and almost automatically to such discourses, non-supporters, on the other hand, automatically rejected them:

I would not do what they said. I do not even listen to them. I turn off the TV when I see them (P10). Because our sample was composed of individuals that have contrasting attitudes - those who support the government's political ideology and those who do not - we were able to observe how polarisation between these groups effectively functions. We argue that it is the power and dominance of the discourse that resulted in the polarisation of these groups - that is, the discourse consumers. We further argue that even the rejection of such discourses implies something significant, namely that the ideas in circulation are influential and create attitude change. This was clear in the following quote:

When it comes to children, I would not follow someone else's advice. They (statesmen) recently declared that they support four children. Next they will support five. I would not trust them and make more children. I had a tubal sterilization. How long will they look after me? Look after my five children? I do not trust that. Let's say that the state helped you until you die, but you mentally grow old. That is why,] I think having many children is selfish. We witness the ones with four or five children. Children wander the streets. If you cannot look after your children. then why do have kids? Is that it? Is it your trust in AKP that makes you have children? (P2). 
The idea of narrative engagement suggests that individuals navigate a polyphonic context in which multiple storylines circulate and compete for dominance and primacy in individual appropriation (Clara, 2020). According to political psychology, such situations are affected by multilevel approaches to the person in context in which individuals assume particular voices (Hammack \& Pilecki, 2012) in their personal narratives that link to particular political interests in a given way. Our participant was clearly influenced by these discourses:

I would be lying if I say that I am not influenced by the "three children" [narrative]. Actually, it affected my parents more. They said: "have three kids, everyone supports it" (P5).

A personal sense of the self through narratives "serves to create a sense of personal coherence and collective solidarity and to legitimize collective beliefs, emotions, and actions" (Scuzzarello in Bevelander \& Peterson, 2014). Legitimisation is realised by the use of personal experiences (Reyes, Antonio, 2011). Here, legitimisation refers to adopting a type of social behaviour. This justifies behaviour within the context by providing personal arguments that explain our social actions and ideas (Holmes, 2018). In addition, the act of legitimising or justifying is related to a goal, which, in most cases, seeks others' support and approval.

P4: Now, statesmen should know something, right? They are also parents. When you have children, then you and your husband become a family. Without children, it is not family.

Interviewer: Is it necessary to have three children for that?

P4: No. Of course not. But if it is going to be a baby boy, then why not have it?

Hence, having the third child is also a way to acquire social approval. Becoming a family is significant, since it is an accepted way to embed oneself into the social order. Such social acceptance also refers to having children, and for some it is having a son:

$\mathrm{SAD} / \mathrm{JSR}$

Cilt / Volume 23 Say1 / Number 2 
Our families supported the third child. They said; "Make the third child, it might be male". Actually, it was a he. We sought a male child (she laughs). I am glad that we did (P7).

Having a son symbolises the continuation of the family name and family traditions (Kağıtçıbaşı \& Ataca, 2005) A preference for sons is parallel to patriarchal family patterns and is an outcome especially related to mothers' material dependencies on adult sons (Kağıtçıbaşı, \& Ataca, 2005: 333).

\section{Explicit Barriers in the Healthcare System}

In authoritative systems, the organisation of social institutions is the main subject of interest for political authority (Plaggenborg, 2012). Sexuality represents an important site of the functioning of political power (Foucault, 1990). Foucault noted in History of Sexuality that discipline emerged in the 'circumscribed spaces' of sovereign power, such as the army, the school, and the prison. This combination of discipline and sovereignty is a basic characteristic of the stable and enduring governmental edifice of European Absolutisms, in which heterogeneous technologies of power were combined. For instance, the governing of sexuality and reproduction, the regulation of domestic and intimate relations, and family become the subject of political slogans that function as technologies of power. As a result, encouraging at least three children becomes not only a declaration of pro-population sentiments, it contains the potential for an intentional organisation of the family as a social institution.

For discursive institutionalism, social institutions are internal to the sentient agents, serving as structures both created and changed by those actors (Korkut, et al., 2016). The intentional organisation of institutions that would impact actors' behaviour is an outcome of discursive institutionalism. The data we gathered from the Turkish Family Health and Planning Foundation (TAPV) suggests that there has been a radical shift of perspective in the health care system concerning reproduction and population control in last ten years. According to the General Director of TAPV, in 1990s and in early 2000s, the Ministry of Health deployed an integrated paradigm towards different actors of population control and population health. In 
recent years, close relations between the public sector, actors in health care and NGOs have been diminished. The loosening up of relations not only changed the implications for the health care system but also affected the content of programmes provided by the Ministry to educate first step health care services. First step health care services were supposed to contain protective knowledge about reproduction and contraception, but the paradigm shift brought changes in the definition and practice of health care services. Implications towards population control have lost their primary status while definitions of service protocols have changed for the provision of services for doctors; pregnancy and postnatal periods have been given primary significance.

We conducted a qualitative research in İstanbul, though the final report is not ready yet. We found out that women who want to get contraception and first step health care regarding reproduction gave up hope and stopped asking for service. With this decrease in women's demand, we can see the impact of policies of the statesmen (Interview at TAPV).

Moreover, the exclusion of contraceptives and family planning counselling in family health centres from performance measures, as well as low performance points given to abortion in hospitals and the periodic irregularities in contraceptive supplies, seem to be in line with the pronatalist policy of the AKP. It is also indicated by others (Dayı \& Karakaya 2018; O’Neil, 2017) that the discourse on abortion was successful in creating confusion in the minds of health providers and women and putting pressure on medical workers not to discuss or provide abortions and, at times, contraceptives. Thus, abortion and contraception are still legal in Turkey, although legal change has never been needed to restrict them.

As we argued above, the organisation of social institutions is the kernel for the interest of political authority. A paradigm shift in the health care system produces new practices and perspectives regarding population issues. What is formerly significant loses its primary status, and new formation in the system creates a new framework for people's actions. Bourdieu refers to a similar framework as the habitus in which human 
beings act by following the institutions of certain logic of practice. Habitus determines agents' ability to make sense of a given context, that is, to get it right in terms of the ideational rules or 'rationality' of a given discursive institutional setting (Schmidt, 2010). This is crucial for the capacity of the discourse to maintain taken-for-granted behaviour.

\section{Environment: The Impact of Polyphonic Messages}

The capacity of a new political discourse is related to its consistency with the given discursive setting along with the hegemonic ideals, which are embedded in consumers' habitus. Religious ideals, rules, social norms, and gender roles might be determinants of such discursive settings. A political discourse, when it is circulated, needs to confirm the already existing ideals to reach its potential capacity. Moreover, our argument is derived from Van Dijk's (1998) interpretation of mind management at a societal level in his definition of social cognition:

...socially shared representation of societal arrangements, groups and relations, as well as mental operations such as interpretation, thinking and arguing, interference and learning among others, that define what we understand (Van Dijk, 2000:34).

Thus, the maintenance of social cognition is usually supported by the collective reality served by external actors. Here we focus on the role of external actors in enhancing a discourse's capacity. The majority of interviewees reported that they had decided to have a third child because they had been verbally encouraged by extended family, neighbours and friends:

I did not want the third child. My husband did. Everybody wanted. My relatives, friends. They supported so that there would not be an age gap between my kids. So that they would grow up together. We (she and her husband) also wanted that (P6). 
This narrative raises the following question: did the participant really want a third child, or did the mother confirm the inspiration of others? Such an array of information, comprised of nested cultural beliefs, is derived from social relationships and is in turn combined with the practical experience in child raising (Vaughan, 2002). Moreover, obedience to the collective will might, in this case, even be read as a search for approval. As we discussed earlier, approval serves as a source of personal justification that occurs as a result of personal appropriation. Such search for approval can also be motivated by the urge to gain power and social acceptance.

As our aim is to examine how discourse triggers deliberations of specific issues, we are also interested in the determinants behind such triggers. In some cases, these were unconscious, thus unknown to the person: "I do not know how, I just decided to have the third child". But how is the conceptualisation of what is "right" or "appropriate" (Reyes, 2011) made? We argue that they are ideologically shaped and defined by the discourses created within one's social group.

I: I also would like to ask about state incentives (for three children). Do you think they are effective?

Nurse: I think the amount of the incentive is not important. Its existence is important. Also, there is acceptance to be gained in it.

I: Gaining acceptance through three children?

Nurse: Yes. In our neighbourhood women are always together. Relatives stay in the same apartments. They become neighbours. They affect each other. (Nurse, District Health Clinic)

The quotation above reveals the importance of social acceptance. Such acceptance depends on one's conformity to the norms of the group, and in this case, it was having at least three children.

People seem to define and adjust their identity according to the commonly perceived paradigms. As recent data shows, people identify whether something is moral or immoral, right or wrong, based on strong, 
intuitive reactions to stimuli (Haidt, 2001). Hence, they do not question the cultural framework surrounding it or the others' influence on their decisions. However, in some instances the common norms, even if they are accepted by many, may not support the discourse under certain conditions. This is the case, for instance, in our so-called opposition sample, where they created their own form of rationalisation to support their disobedience:

After I had tubal sterilization, people around me told that I had sinned. They said that I have a metal in my body, and that I cannot get clean enough; I cannot perform proper ablution. But if I did not get it done, I would have four children maybe five maybe six. Then I would sin because I would do wrong to my children (P2).

Personal experiences are a part of the legitimisation process because they provide the audience the opportunity to rationalise the course of action. Discourses create social representations of the world that reflect and actively construct reality by ascribing meanings. For the members of particular groups with opposing ideologies, the same discourse may produce different cognitive structures and social representations. Their rejection of the discourse seems to appear from personal experience, which produces an anti-thesis.

\section{Abortion: Whose Decision?}

The anti-abortion statements are part of the reproduction discourse in Turkey. We take it is an extension of the pro-population declarations since the opposition to abortion and encouragement for more children were justified by the same rationale. The emphasis on the 'strong Turkish family' is reflected in the antiabortionist and pro-birth rhetoric (Altunok, 2016). Furthermore, the discourse highlights the benefits of strengthening the family and defines more responsibility for women as the primary care takers.

Other studies have reported that the female body has always been a site for state policies regulating its procreative capacities (Outshoorn et al., 2012). In her analysis of the legal codes on rape, abortion and

$\mathrm{SAD} / \mathrm{JSR}$

Cilt / Volume 23 Say1 / Number 2 
adultery in Ottoman / Turkish, French and Italian contexts, Miller (2007), for instance, argues that gendered citizenship is created not through an exclusion of women but through a mechanism of bio-politics that is 'relentlessly inclusive' (Miller, 2007: 353). Miller further asserts that women's sexuality - and particularly the womb - has increasingly become a socio-political space for states, as the regulation of the sexual or reproductive capacities of women and any action directed at them is directly linked to the 'national' political identity (De Cillia \& Wodak, 1999). Nationalistic ideology defines the ideal women as 'someone who reproduces the political aims underlying the demographic policies' (Ünal \& Cindioğlu, 2013). This image of womanhood is also supported by family guidance and counselling offices to ensure continuing integrity of the family ${ }^{12}$.

Although there has been no legal change, there are many reports of restrictions on abortions in state hospitals (Candaş \& Silier, 2014) along with the practice of contacting the woman's husband or father when the pregnancy has been confirmed without the consent of the woman in question (Tolunay, 2014). Approximately $14 \%$ of women in Turkey reported having had an abortion in their lifetime. ${ }^{13}$ According to a recently published report concerning abortion services in state hospitals in Turkey, 53 of 81 provinces do not have a state hospital that provides abortion care without restriction as to reason (Ball et al., 2016). Thus, the same report notes that "abortion is legal but is not necessarily available". The data from TAPV confirms the fact that doctors declare they do not perform abortions:

The first step health care services need to include is contraception and protective services for reproduction. The second step in health care should include abortion services. Neither of them is practically available. These services are not reflected in the workloads. They do not count as

12 http://www.cankayamuftulugu.gov.tr/aileirsat.htm

13 Hacettepe University Institute of Population Studies. 2013 Turkey Demographic and Health Survey. http://www.hips.hacettepe.edu.tr/eng/TDHS_2013_main.report.pdf Accessed on: 13.05.2020.

$\mathrm{SAD} / \mathrm{JSR}$

Cilt / Volume 23 Say1 / Number 2

\section{6}


performance; there is not even a box to tick. When women ask for it, they hear "no" as an answer. Doctors also do not care (General Director of TAPV)

According to General Director of TAPV, doctors feel psychological and social pressure in the strict political atmosphere. Thus, abortion is framed as taboo for medical experts. Framing a social reality, by using justifiable theses for the majority, establishes organising principles that are socially shared and persistent over time (Reese et al., 2001). Frames categorise a given situation for the public, and this categorisation later determines how the public reasons (Johnson, et al., 1993).

In line with this argument, our participant from TAPV also stated that as women receive negative answers for contraception or abortion, they tend to think that these services are not legal. Our participant also noted that if some people falsely believe that abortion is illegal, change in the reproductive behaviour is also possible with "proper perception management" (Lakoff \& Johnson, 1980: 157 in Koller, V. 2005):

TAPV: It is not only the ordinary people, I recently participated in a meeting where a reporter asked me whether abortion is legal. A reporter! We practice at schools. Students think that it is illegal. There are doctors who think abortion is illegal! Doctors! Therefore, there is no need for law making or removal. Proper perception management is enough.

Interviewer: You know, our main question in this research is whether a behaviour change can be managed....

TAPV: I know. I think it can certainly be managed. There are so many examples from the field. For instance, although there is contraception, doctors are reluctant to provide the medicine. They feel nervous providing it. I cannot understand how we came to this point. One can rule a country without moving a finger... 
Frames define the boundaries of the discourse concerning an issue and pervade a perceived reality to promote the definition of a particular problem, causal interpretation, moral evaluation, and / or recommended treatment (Pan \& Kosicki, 1993). Anti-abortion rhetoric in Turkey has followed a similar path. Although abortion was legal, it was defined to be a cause of stagnation in population growth. Another conspiracy theory suggested that stagnant population is a way to wipe the Turkish nation off the world stage and stop Turkey's economic growth (Sümer \& Eslen-Ziya, 2017). Until 2008, the stagnation thesis framed pro-birth discourses and anti-abortion declarations, although the majority in our study reported a reluctance towards abortion due to religious reasons.

I have not had any abortions. Thank Allah. Even if the baby were handicapped, I would not do it. My husband would not let me either. We would look after it. Allah gives the healthy and also the handicapped. (P1).

I would not want my wife to have an abortion. It comes from us after all. It comes from Allah (P3).

Because of religion, I would never take a life. (P1).

Religious and moral emphasis was made to define discourse boundaries and to support the pro-population idea. Even though there is a legal basis for abortion, channels that lead women to take advantage of abortion services are usually blocked. At the state and research hospitals, women need written permission from their husbands (Ball et al., 2016). All participants except for two stated that they are against abortion. However, the decision of abortion is not only for women to make; it also becomes the decision the extended families.

I wanted to give birth to my child. My husband did not. He found a doctor for an abortion. When I found out what he did, I talked to my father-in-law. I told him that his son is forcing me to have an abortion. He (father-in-law) stood in the way. I did not get the abortion. (P1) 
P5: Both sides were against abortion (both extended families) I found out my pregnancy at my second daughter's birthday. I wanted to get an abortion. Our families disapproved.

Interviewer: What would have happened if you had not told them about your abortion?

P5: I would not have done it without approval. I did not want to do something I might regret. I am happy that I did not get it done.

The decision concerning abortion is understood to be a social decision for some women. They are conditioned to be the object of this decision. Meanwhile, husband and elders, as privileged subjects, sometimes have a bigger say in that equation. As mentioned in the previous section, privileged people in the social group have the capacity to access certain social situations where they can influence others' decisions. In framing an issue, each social aggregate "acts out" its discursive as well as sociological binding (Pan \& Kosicki, 1993). Thus, by making the abortion decision dependent on the husband's consent, the framing of abortion creates a material barrier, which does not nullify the legality of abortion, but it indirectly and socially restrains it. Thereby, social situations, such as abortion, are typically surrounded not only by mental fences but also bound to material barriers such as social relations. Both personal and social fences are, we argue, strategically embedded in the political discourse concerning social situations.

\section{State Incentives}

Until now, we have argued that strategic narratives embedded in political declarations can generate a discursive space for the subject population. Supplementary background factors such as the given sociocultural setting of the group, religious justifications and the influence of hegemonic others enhance the discourse's capacity to set off action. This following thus focuses on the impact of state incentives as material contributor to the pro-population discourse.

If we were to read population politics from an institutionalist perspective, the existence of childcare facilities and family-friendly policy practices are factors affecting women's decision to bear children (Frey,

$\mathrm{SAD} / \mathrm{JSR}$

Cilt / Volume 23 Say1 / Number 2 
2003). Reproductive choices for women are influenced by equal pay legislation, paid parental leave from one's job, and high-quality public childcare (Einhorn, 1993). Attar (2013) in his research regarding incentives and reproduction, indicates that newly married couples prefer to have more children if they have the economic power to afford it. He states that state incentives and factors that would decrease the cost of raising children determine the level of reproduction in Turkey (Attar, 2013:4) Although the sample of this study does not contain working women, we believe that state incentives regarding child care might be significant in any decision to have children. It is our argument that formal regulations are important to the extent that their procedures may eventually create an effect on individuals' behaviour and attitudes (Korkut, \& Eslen-Ziya, 2011).

Within the frame of the Family Package published in the Official Gazette (15 May 2015), married couples can access monetary incentives for birth, children, and breastfeeding. The total value / cost of the care is approximately 4.521 TL (1.240 Euro) for couples with one child, and it can reach up to 14.000 TL (3.840 Euro) for families with three children. For the couples who have their child / children after 15 May 2015, a monetary incentive of 300 TL ( 83 Euro) for the first child is provided. Couples with a second child receive 400 TL (109 Euro) and 600 TL (164 Euro) for the third child. The incentive "is one time only". However, a breastfeeding incentive of up to 122 TL (34 Euro) is paid monthly. The applications are run through centres for Social Services ${ }^{14}$.

Apart from three participants, the respondents reported that they received regular monetary help from the state. Since the Family Package is a new practice, most participants stated they only received monetary assistance from the state for their last child.

\footnotetext{
${ }^{14}$ http://ekonomi.haber7.com/turkiye-ekonomisi/haber/2109691-3-cocugu-olana-14-bin-lira-destek

$\mathrm{SAD} / \mathrm{JSR}$

Cilt / Volume 23 Sayı / Number 2 
P6: I could not benefit from the incentives for my daughters. I received breastfeeding money for my son. It was $800 \mathrm{TL}$. At the time I had my daughters, there were no incentives.

Interviewer: Would you benefit from the incentives, then?

P6: Of course, I would. Children are costly; diapers, baby food....

It is significant to note that the monetary incentives are given to mothers only. The policy implies that mothers are associated with the role of main caregiver. Other studies show that socially conservative discourses operate in ways to allocate care-giving roles to women (Lazar, 2000). The conservative tone of pro-natalism vies for the protection of a religious-cultural way of life against outside influences and conspiracies seeking to destroy traditional values.

We received birth aid for my little girl. Then we got it for my son too. They also give breastfeeding money. I get Ramadan aid, and I sometimes get assistance for the feast of sacrifice. I mean if state does not help, it is difficult to raise a child. The needs never end (P4).

The narrative shows that incentives for childbirth might be conceived in the same category with religious aid. This is because all kinds of state incentives are provided by the same institution. The regulation and distribution of state funded assistance has a significant impact on the operation of population policies. Certain common beliefs related to gender issues, religion, and social norms are used by politicians when they form a declaration about population issues. Both policy makers and the public use these beliefs as normative yardsticks (Korkut \& Eslen-Ziya, 2011:411) to merge discursive frames and material practices. Thus, the same institution providing family incentives and religious aid is materialised in people's mind to foster the state discourse's impact on supporting the family's economy under the frame of population issues.

Overall, population politics depends upon ideas regarding gender relations and definitions about ideals. Institutional practices deserve attention because they regulate population politics to the extent that they 
dominate the functioning of population politics, so long as the ideas embedded in pro-population discourse and formal regulations assert the maintenance of social reconciliation. 


\section{CONCLUSION}

The pro-population discourse of the AKP exemplifies the functioning of bio-politics through discursive governance in the Turkish context. Our study shows that when pro-population political ideas discursively spread, this political discourse becomes a part of public sentiment. Then, as the pro-population narrative becomes common to the public, reactions to the discourse leads to the differentiation of social groups. Among our respondents, we had two opposing poles of participants. Those directly or indirectly influenced by the political declarations in a positive way accepted its political discourse; those who viewed it negatively did not. We argue that both groups show how the pro-population discourse has the capacity to function by favouring the dominant political view regardless of whether participants were for or against it.

According to Foucault, bio-politics" "first objects of knowledge and the targets it seeks to control" (2003: 243). For instance, "the mortality rate has to be modified or lowered; life expectancy has to be increased; the birth rate has to be stimulated". Such interventions share with disciplinary power the aim to "maximize and extract forces". Nevertheless, they do not work through the minute controls of the body. Instead, they aim to "establish an equilibrium, maintain an average, establish a sort of homeostasis, and compensate for variations within this general population" to "optimize a state of life" (Foucault, 2003: 246). In our study, we argue that asserted slogans encouraging three children and less abortion not only literally created a state of life but also provided a limited space for some couples to think that they can afford/ care for more.

We argue thus that there is a process for formation and articulation concerning the discourse in which consumers receive ideological messages though strategically identified steps. Further, we noted certain steps necessary for the construction of the pro-population state discourse. The steps mentioned are identified through the chronological declaration of political actors such as encouraging couples to have three children, making an analogy of abortion as a "tragic accident", making statements against c-sections and finally implying that contraception has no place in Islam. In our conceptualisation, we call these stages 'discourse 
generation', which implies strategic calculations embedded within the quality of discursive composition.

As individuals engage with strategically calculated narratives, they navigate a polyphonic context in which multiple storylines circulate and compete for dominance and primacy in individual appropriation. Our findings show that supplementary background factors, such as the given sociocultural setting of the group, religious justifications and the influence of hegemonic others, are effective in allowing the discourse's capacity to inspire action. The regulation and distribution of state-funded assistance also has a significant impact on the operation of population policies.

The capacity of a political discourse is also based on its consistency with the given discursive setting, along with the hegemonic ideals that are embedded in audiences' habits / norms. In the light of our limited data, we also see that religious ideals, rules, and social norms determine as much as institutions, religious or religiously inspired actors, and civil society organisations that take an active role in mainstreaming the propopulation discourse at different levels. In addition to the circulation of discursive messages, the intentional organisation of institutions was reported to have an impact on actors' behaviour, which we take as an outcome of discursive institutionalism, where discursive messages operating as belief systems and political ideologies become a dominant source of influence.

The data we gathered from the TAPV suggests that there has been a radical shift of perspective in the health care system concerning reproduction and population control in last ten years. Protective population control and contraception services are blocked by the new structure of the performance system since these services have no place in workloads. Abortion is one of the services that has become taboo, both for patients and doctors. It is important to note that pro-population messages are based on a will to assert control over the female body. Within pro-population discourse, female subjectivity is constructed in the familial sphere with the primary responsibility of giving birth. Although the abortion debate did not institute a legal change, and the current Population Planning Law (1983) legalises safe abortion on request during the first 10 weeks 
of gestation, it is shown that there has been a de facto ban on abortions in state hospitals in the last years (Kadir Has Uni., 2016).

To conclude, discursive messages of the government are perceived either as legitimate, acceptable and good for the public (hence followed without questioning) or just the opposite (rejected without questioning). In the end, irrespective of the participants' political position, conservative discourse introduced by the government influences the public's decisions. 


\section{ÖZET}

Nüfus yanlısı politikaların söylemsel yönetişimi; siyasal otoritelerin çıkarlarını sürdürmek adına politik söylemde fikirlerin yayılması için kasıtlı olarak seçilen sloganları kullanan norm tabanlı yönetişim mekanizmalarını ifade eder. Bu tür fikirler, siyasa üretme kısıtı olmaksızın yönetişimin kamusal alan içinde sosyal temsiller oluşturmasını sağlamak yoluyla modern iletişim teknolojileri aracılığıyla yayılabilir. Bu çalışmada, 2008'den sonra Türkiye'deki nüfus yanlısı devlet söyleminin söylemsel yönetişime örnek teşkil ettiğini savuınuyoruz. Elde ettiğimiz bulgular; söylemsel mekanizmaların, direkt siyasa yapılanması olmadan evli çiftlerin üreme tutumlarında bir değişikliğe yol açabileceğini göstermektedir.

$\mathrm{Bu}$ çalışma bulguları çerçevesinde, söylemsel nüfus politikası örneği üzerinden yönetişim tartışmalarına yeni bir boyut kazandırmayı amaçlamaktadır. Türkiye'deki nüfus artışı yanlısı devlet söylemi aracılı̆̆ıyla, siyasetçilerin kamusal aklı nasıl etkilediğine ve önemli politika değişikliği yaratmadan söylemsel düzeyde belli mesajları dolayıma sokarak tutum değişikliğine yol açtığına dair bir örnek teşkil ettiğini savunuyoruz. Temel argümanımız, 2008'den sonra nüfus artışı yanlısı söylemin evli çiftlerin üreme tutumlarında bir değişikliğe yol açmış olabileceği varsayımına dayanıyor. Özellikle, slogan haline gelen siyasi söylemlerin etkisiyle "üç çocuk" sahibi olma kararlarının yanı sıra, kürtaj konusundaki olası isteksizliğe odaklanmaktayız. Bu çerçevede, 2008 sonrasında üçüncü çocuğa karar veren on kadın ile derinlemesine görüşmeler yapılmıştır. Görüşmeler, Ankara ve İzmir'de gerçekleşmiş, kar topu metodu ile katılımcılara ulaşılmıştır.

Bulgularımız, doğurganlık konusunda 2008'den beri yaygınlaşan Türk siyasi söylemindeki nüfus yanlısı anlatıların kamuoyunda etkili olduğunu gösteriyor. "Aile ve üreme kamusal alanda söylemsel yönetişimin etkilerini anlamak için önemli bir örnek oluşturabilir” varsayımı ile yola çıktığımız bu araştırmada; kamusal alanda dolayıma giren fikirlerin sosyal aktörleri davranış ve tutum değişikliğine yönelendirebileceği gözlemlenmektedir. "3 çocuk" ve kürtaj karşıtı söylem kapsamında bu tür davranışsal değişimlerin 
mekanizmalarını anlamak ve bu yolla söylemsel yönetişim tartışmasını bir sonraki boyuta taşımayı amaçlamaktayız.

\section{Declaration of Conflicting Interest}

The authors declared no conflicts of interest with respect to authorship and/or publication of this article.

\section{Acknowledgment}

We would like to thank the anonymous reviews we received on this paper. Finally, our gratitude to our interviewees who took the time to engage with our project. 


\section{BIBLIOGRAPHY}

Acar, F., Altunok, G. (2013). The 'Politics of Intimate' at the Intersection of Neo-Liberalism and NeoConservatism in Contemporary Turkey. In Women's Studies International Forum, Vol. 41, pp. 1423. Pergamon.

Agamben, G. (1998). Homo Sacer: Sovereign Power and Bare Life. Stanford University Press.

Agamben, G. (1999). The Man Without Content. Stanford University Press.

Altunok, G. (2016). Neo-Conservatism, Sovereign Power and Bio-Power: Female Subjectivity in Contemporary Turkey. Research and Policy on Turkey, 1(2), 132-146.

Arat, Y. (2010). Religion, Politics and Gender Equality in Turkey: Implications of A Democratic Paradox?. Third World Quarterly, 31(6), 869-884.

Attar, M. A. (2013). Growth and Demography in Turkey: Economic History vs. Pro-Natalist Rhetoric.

Ball, T., Dagger, R., \& O’Neill, D. I. (2016). Political Ideologies and the Democratic Ideal. Taylor \& Francis.

Blühdorn, I., \& Butzlaff, F. (2019). Rethinking Populism: Peak Democracy, Liquid Identity and the Performance of Sovereignty. European Journal of Social Theory, 22(2), 191-211.

Bock-Côté, M. (2015). Le Multiculturalisme Comme Religion Politique. Le Débat, (4), 122-136.

Boratav, H. B., Fişek, G. O., \& Ziya, H. E. (2014). Unpacking Masculinities in the Context of Social Change: Internal Complexities of the Identities of Married Men in Turkey.Men and Masculinities, 17(3), 299-324.

Bugra, A. (2007). Poverty and Citizenship: An Overview of the Social-Policy Environment in Republican Turkey. International Journal of Middle East Studies, 39(1), 33-52.

Candas, A., \& Silier, Y. (2014). Quietly Reverting Public Matters into Private Troubles: Gendered and Class-Based Consequences of Care Policies in Turkey. Social Politics, 21(1), 103-123. 
Chiapello, E., \& Fairclough, N. (2002). Understanding the New Management Ideology: A Transdisciplinary Contribution from Critical Discourse Analysis and New Sociology of Capitalism. Discourse \& Society, 13(2), 185-208.

Clarà, M. (2020). Meaning and the Mediation of Emotional Experience: Placing Mediational Meaning at the Center of Psychological Processes. New Ideas in Psychology, 58, 100776.

Collier, S. J. (2009). Topologies of Power: Foucault's Analysis of Political Government Beyond 'Governmentality'. Theory, Culture \& Society, 26(6), 78-108.

Day1, A., \& Karakaya, E. (2018). Transforming the Gendered Regime through Reproductive Politics: Neoliberal Health Restructuring, the Debt Economy and Reproductive Rights in Turkey. Les cahiers du CEDREF. Centre d'enseignement, d'études et de recherches pour les études féministes, (22), 158-192.

De Cillia, R., Reisigl, M., \& Wodak, R. (1999). The Discursive Construction of National Identities. Discourse \& Society, 10(2), 149-173.

Dirlik, A. (2012). The Idea of A 'Chinese Model’: A Critical Discussion. China Information, 26(3), 277302.

Einhorn, B. (2002). Cinderella Goes to Market, pp. 156-57. Verso.

Esposito, R. (2010). Communitas: The Origin and Destiny of Community. California: Stanford University Press.

Foucault, M. (1990). The History of Sexuality: An Introduction, Volume I. Trans. Robert Hurley. New York: Vintage, 95.

Foucault, M. (2003). The Essential Foucault: Selections from Essential Works of Foucault, 1954-1984.

Foucault, M. (1984). The Foucault Reader. Pantheon.

Frey. (2003). Direct Democracy for Transition Countries. Journal for Institutional Innovation, Development and Transition, Vol. 7, 42-59.

Hacettepe University Institute of Population Studies (2013). 2013 Turkey Demographic and Health Survey. http://www.hips.hacettepe.edu.tr/eng/TDHS_2013_main.report.pdf Accessed on: 18.07.2020.

$\mathrm{SAD} / \mathrm{JSR}$

Cilt / Volume 23 Say1 / Number 2 
Haidt, J. (2001). The Emotional Dog and Its Rational Tail: A Social Intuitionist Approach to Moral Judgment. Psychological Review, 108(4), 814.

Hammack, P. L., \& Pilecki, A. (2012). Narrative As A Root Metaphor for Political Psychology. Political Psychology, 33(1), 75-103.

Holmes, S. (2018). Responses to Warnings about the Impact of Eating Disorders on Fertility: A Qualitative Study. Sociology of Health \& Illness, 40(4), 670-686.

Kağıtçıbaşı, C., Ataca, B. (2005). Value of Cchildren and Family Change: A Three-Decade Portrait from Turkey. Applied Psychology, 54(3), 317-337.

Kandiyoti, D. (1998). Some Awkward Questions on Women and Modernity in Turkey.

K1lıç, A., Göçmen, İ. (2018). Fate, Morals and Rational Calculations: Freezing Eggs for Non-Medical Reasons in Turkey. Social Science \& Medicine, 203, 19-27.

Koller, V. (2005). Critical Discourse Analysis and Social Cognition: Evidence from business Media Discourse. Discourse \& Society, 16(2), 199-224.

Korkut, U., \& Eslen-Ziya, H. (2011). The Impact of Conservative Discourses in family Policies, Population Politics, and Gender Rights in Poland and Turkey. Social Politics, 18(3), 387-418.

Korkut, U., \& Eslen-Ziya, H. (2016). The Discursive Governance of Population Politics: The Evolution of A Pro-Birth Regime in Turkey. Social Politics: International Studies in Gender, State \& Society, 23(4), 555-575.

Korkut, U., \& Eslen-Ziya, H. (2017). Politics and Gender Identity in Turkey: Centralised Islam for SocioEconomic Control. Routledge, 2017.

Johnson, E. J., Hershey, J., Meszaros, J., \& Kunreuther, H. (1993). Framing, Probability Distortions, and Insurance Decisions. Journal of Risk and Uncertainty, 7(1), 35-51.

Lakoff and Johnson, 1980: 157 in Koller, V. (2005). Critical Discourse Analysis and Social Cognition: Evidence from Business Media Discourse. Discourse \& Society, 16(2), 199-224.

Lazar, M. M. (2000). Gender, Discourse and Semiotics: The Politics of Parenthood Representations. Discourse \& Society, 11(3), 373-400.

$\mathrm{SAD} / \mathrm{JSR}$

Cilt / Volume 23 Say1 / Number 2 
Lemke, J. L. (2000). Across the Scales of Time: Artifacts, Activities, and Meanings in Ecosocial Systems. Mind, Culture, and Activity, 7(4), 273-290.

Lemke in Weiss, G., \& Wodak, R. (Eds.). (2007). Critical Discourse Analysis. New York, NY: Palgrave Macmillan.

Mahendran, A., \& Vedaldi, A. (2015). Understanding Deep Image Representations by Inverting Them. In Proceedings of the IEEE Conference on Computer Vision and Pattern Recognition, 5188-5196.

O'Neil, M. L. (2017). The Availability of Abortion at State Hospitals in Turkey: A national Study. Contraception, 95(2), 148-153.

Miller, D. (2007). National Responsibility and Global Justice. Oxford University Press.

Müftüler-Bac, M. (1999). Turkish Women's Predicament. Women's Studies International Forum, Vol. 22, No. 3, 303-315. Pergamon.

O'Leary, R., Van Slyke, D. M., Kim, S. (2010). The Future of Public Administration Around the World: The Minnowbrook Perspective. Georgetown University Press.

Outshoorn, J., Kulawik, T., Dudová, R., \& Prata, A. (2012). Remaking Bodily Citizenship in Multicultural Europe: The Struggle for Autonomy and Self-Determination. In Remaking Citizenship in Multicultural Europe, 118-140. Palgrave Macmillan, London.

Ongur, H. Ö., \& Zengin, H. (2019). Reading Agamben Backwards: Syrian Refugees, Biopolitics and Sovereignty in Turkey. Social Science Information, 58(1), 103-120.

Pan, Z., \& Kosicki, G. M. (1993). Framing Analysis: An Approach to News Discourse. Political Communication, 10(1), 55-75.

Plaggenborg, S. (2012). Ordnung und Gewalt: Kemalismus-Faschismus-Sozialismus. Walter de Gruyter.

Polat, N. (2020). Negotiating Masculinities: Reproductive Technologies, Biosocial Exclusion and Men's Engagements in Turkey. NORMA, 1-16.

Reese, S. D., Gandy Jr, O. H., \& Grant, A. E. (2001). Framing Public Life: Perspectives on Media and Our Understanding of the Social World. Routledge. 
Reyes, A. (2011). Strategies of Legitimization in Political Discourse: From Words to Actions. Discourse \& Society, 22(6), 781-807.

Schmidt, V. A. (2010). Taking Ideas and Discourse Seriously: Explaining Change Through Discursive Institutionalism as the Fourth 'New Institutionalism'. European Political Science Review, 2(1), 125.

Scuzzarello, S. (2014). Narratives, Normativity and Local Policy-Making. Crisis and Migration: Implications of the Eurozone Crisis for Perceptions, Politics, and Policies of Migration, 131-156.

Sunar, D., Fisek, G. (2005). Contemporary Turkish Families. Families in Global Perspective, 169-183.

Sümer, S., \& Eslen-Ziya, H. (2017). New Waves for Old Rights? Women's Mobilization and Bodily Rights in Turkey and Norway. European Journal of Women's Studies, 24(1), 23-38.

Tolunay, Ö. İ. (2014). Women in Erdogan's Turkey. New Politics, 14(4), 49.

TNSA (2013). Türkiye Nüfus ve Sağlık Arastırmas1/Demographic and Health Survey. Hacettepe University Institute of Population Studies Ankara, Turkey. Retrieved from: http://www.hips.hacettepe.edu.tr/TDHS_2013_main.report.pdf .Accessed on: 13.05.2020

Ünal, D., Cindoglu, D. (2013). Reproductive Citizenship in Turkey: Abortion Chronicles. In Women's Studies International Forum, Vol. 38, 21-31. Pergamon.

Van Dijk, T. A. (1998). Ideology: A Multidisciplinary Approach. Sage.

Van Dijk in Heather, N. (2000). Religious Language and Critical Discourse Analysis: Ideology and Identity in Christian Discourse Today. Peter Lang.

Van Dyck, E. (2013). Facing Eugenics: Reproduction, Sterilization, and the Politics of Choice. University of Toronto Press.

Vaughan, F. (2002). What is Spiritual Intelligence? Journal of Humanistic Psychology, 42(2), 16-33. 37.

Y1lmaz, H. (2008). Conservatism in Turkey. Turkish Policy Quarterly, 7(1), 57-63.

Žižek, S. (2004). The Ongoing “Soft Revolution”. Critical Inquiry, 30(2), 292-323.

$\mathrm{SAD} / \mathrm{JSR}$

Cilt / Volume 23 Say1 / Number 2 
https://www.hurriyetdailynews.com/abortion-sparks-raging-debate-in-turkey-21740. Accessed

on 13.05.2020

http://www.bbc.com/news/world-europe-36413097. Accessed on 13.05.2020

http://www.yenisafak.com/gundem/dindar-nesil-yetistirecegiz-2424175. Accessed on 12.04.2020

http://www.cankayamuftulugu.gov.tr/aileirsat.htm._Accessed on 10.04.2020

http://ekonomi.haber7.com/turkiye-ekonomisi/haber/2109691-3-cocugu-olana-14-bin-lira-destek Accessed on 13.05.2020

https://www.hurriyetdailynews.com/turkish-pm-erdogan-reiterates-his-call-for-three-children-38235 , Accessed on 26.09.2020.

http://www.ntvmsnbc.com/id/25008774/. Accessed on: 18.07.2013

http://www.hurriyet.com.tr/gundem/erdogan-bu-ulkede-dogum-kontrolu-ile-yillarca-ihanet-yaptilar27823289. Accessed on 26.09.2020. 